\title{
Phytochemical, cytotoxic, in-vitro antioxidant and anti-microbial investigation of ethanolic leaf extract of Zizyphus rugosa lam.
}

\author{
Md. Sazzad Hossain ${ }^{1}$, Nizam Uddin ${ }^{1}$, Nahid Hasan ${ }^{2}$, Md. Parvez Hossain ${ }^{2}$, \\ Milon Mondal $^{2}$, Tariqul Islam ${ }^{2}$, Abdullah Faruque ${ }^{2}$, Md. Sohel Rana ${ }^{2}$ \\ ${ }^{1,2}$ Laboratory of Natural Products Research, Department of Pharmacy, Jahangirnagar University, Savar, \\ Dhaka-1342, Bangladesh
}

\begin{abstract}
Zizyphus rugosa Lam. (Family: Rhamnaceae), locally known as "Bon Boroi" or as "Jongli Boroi" in Bangladesh generally found as a herb on the hills in bunches on thorny branches of the Zizyphus rugosa trees. Its bark and wood are used medicinally for dysentery in China, India, Laos, Burma, Sri Lanka, Thailand and Vietnam. Phytochemical screening of the Leaf extract of Zizyphus rugosa Lam showed different phytoconstituents including carbohydrates (monosaccharides, reducing and mixed-reducing sugars), alkaloid, glycosides, steroids, tannins and saponin. No flavonoid was detected. In DPPH and NO radical scavenging methods, IC 50 was moderately satisfactory. IC $C_{50}$ was found $179.713 \mu \mathrm{g} / \mathrm{ml}$ and $769.909 \mu \mathrm{g} / \mathrm{ml}$ respectively compare with the reference ascorbic acid $(15.707 \mu \mathrm{g} / \mathrm{ml}$ and $82.642 \mu \mathrm{g} / \mathrm{ml}$ respectively). In LPO (Lipid peroxidation) assay the Leaf fraction extract showed moderate inhibition potentiality $\left(I_{50} 402.835 \mu \mathrm{g} / \mathrm{ml}\right)$ in comparison to standard drug BHT $\left(I C_{50} 32.94 \mu \mathrm{g} / \mathrm{ml}\right)$. In CUPRAC assays, the fraction was found to possess low Total antioxidant content, good flavonoid, and moderate amounts of phenolics, tannin and alkaloid content. The Leaf fraction extract was found to show good toxicity to Brine Shrimp nauplii, $\left(L C_{50} 212.402 \mu \mathrm{g} / \mathrm{ml} \& L C_{90}\right.$ $10715.91 \mu \mathrm{g} / \mathrm{ml})$ compare with the reference anticancer drug vincristine sulphate $\left(L C_{50} 2.47 \mu \mathrm{g} / \mathrm{ml} \& L C_{90}\right.$ $42 \mu \mathrm{g} / \mathrm{ml}$ ). In the antimicrobial study the fraction showed moderate activity against only one bacterium (Shiggla sonni) while the standard drug Chloramphenicol showed very good zone of inhibition against all five types (Salmonella typhi, Staphylococcus aureus, Shiggla sonni, Salmonella paratyphi, Salmonella grb) of bacteria. These findings provide scientific basis for the use of Zizyphus rugosa Lam. leaf ethanolic extract in traditional medicine in the treatment of aforementioned diseases. The plant also possesses moderate antimicrobial activity, good cytotoxic and good to moderate antioxidant activity.
\end{abstract}

Keywords- Bon Boroi, Dysentery, Rhamnaceae, Zizyphus, DPPH.

\section{Introduction}

Natural products provide a starting point for new synthetic compounds, with diverse structures and often with multiple stereocenters that can be challenging synthetically ${ }^{[1]}{ }^{[2]}$. A natural product is a chemical compound or substance produced by a living organism-found in nature that usually has a pharmacological or biological activity for use in pharmaceutical drug discovery and drug design. Due to have complex structures and expensive to synthesize natural products can only be harvested from their natural sources- a process which can be tedious, time consuming, and expensive, as well as being wasteful on the natural resource. The plants that possess therapeutic properties or exert beneficial pharmacological effects on the animal body are generally designated as "Medicinal plants" ${ }^{[3]}$. Medicinal plants are the richest bio-resource of drugs of traditional systems of medicine, modern medicines, nutraceuticals, food supplements, folk medicines, pharmaceuticals intermediates and chemical entities for synthetic drugs ${ }^{[4]}$. "Medicinal Plants" are various plants that possess therapeutic properties or exert beneficial pharmacological effects on the animal body ${ }^{[5]}$. In fact in the Quran and Bible, about 20 and 125 plants are mentioned, respectively, as being used as medicinal agents to treat various ailments ${ }^{[6]}$. Allopathic and homeopathic systems of medicine today are based doctrine expatiated by Galen ${ }^{[7]}$. The use of herbs to treat disease is almost universal among non-industrialized societies ${ }^{[8]}$. More than 250 medicinal plants are now in common use in the preparation of traditional medicine in Bangladesh ${ }^{[9]}$. Yusuf and Chowdhury (1998) have identified about 550 Bangladeshi medicinal plants and found more than 500 plants effective and Ghani (2003) has enlisted the uses and ingredients of 455 medicinal plants.

'Chunnam' is known to be one of the most prized berries of Goa after 'Kantam'. They are found on the hills in bunches on thorny branches of the Zizyphus rugosa trees and are also sold in local markets. They appear to be pulpy white or pinkish in colour and have a mildly sweet taste. Zizyphus rugosa is a species of plant in the Rhamnaceae family. It is a tree found on hills and mountains below 1,400 m altitude in and its bark and wood are used medicinally for dysentery in Laos, China (Hainan, Yunnan), India, Burma, Sri Lanka, Thailand and Vietnam. It differs from normal Plum in the time of its flowering and fruiting. The flowering time of Zizyphus rugosa occurs after the Rainy season. The size of leaf of Zizyphus rugosa is larger than normal Plum. Its Leaves are elliptic, often rounded from an oblique or cordate base, $5-13 \mathrm{~cm}$ long, densely tawny-villous and paler 
beneath and Fruits are drupe, globose or pear-shaped, about $2 \mathrm{~cm}$ long. The bark of the plant is commonly used in the Indian medicine for the treatment of diarrhoea while the flowers, together with leaves, are used in menorrhagia ${ }^{[10]}$. Different species of the genus Zizyphus like vulgaris, sativa, jujuba,etc. belong to the family Rhamnaceae showed hypoglycemic activity ${ }^{[11]}{ }^{[12]}$. Lupeol, betuline, betulinaldehyde and betulinic acid, isolated from $Z$. rugosa, also showed good activity against a few bacteria. ${ }^{[13]}$. It can be supplemented as a good source of the different important metal requirement of the body ${ }^{[14]}$.

Therefore, the present study was designed to investigate the antioxidant, cytotoxic, anti-microbial properties and phytochemical screening tests of Leaf extract of Zizyphus rugosa Lam. known as "Bon Boroi" or as "Jongli Boroi"

\subsection{Plant Material}

\section{Materials And Methods}

Leaves of Zizyphus rugosa Lam. were collected from the campus of Jahangirnagar University, Savar, Dhaka, Bangladesh and identified by the taxonomist of the National Herbarium of Bangladesh, Mirpur, Dhaka. The voucher specimens of the plants have been deposited in the herbarium for further reference.

\subsection{Extraction}

The leaves of Zizyphus rugosa Lam. (were dried in hot air woven at $55^{\circ} \mathrm{C}$ for 5 days, coarsely powdered and extracted with a mixture of methanol: water $(7: 3, \mathrm{v} / \mathrm{v})$ by a Soxhlet apparatus at $65^{\circ} \mathrm{C}$. The solvent was completely removed and the dried crude extract thus obtained was used for investigation.

\subsection{Phytochemical screening}

The freshly prepared crude extract was qualitatively tested for the presence of chemical constituents. These were identified by characteristic color changes using standard procedures ${ }^{[5]}$

\subsection{Antioxidant activity evaluation}

\subsubsection{Total phenol content determination}

Total phenolic contents of the fractions were determined by Folin-Ciocalteu Reagent (FCR) ${ }^{[15] ~[16] ~}{ }^{1.0}$ $\mathrm{ml}$ plant extracts $(200 \mu \mathrm{g} / \mathrm{ml})$ was added to $5 \mathrm{ml}$ of Folin-ciocalteu (Diluted 10 fold) reagent solution and $4 \mathrm{ml}$ of Sodium carbonate solution was added. Absorbance at $765 \mathrm{~nm}$ was determined using a UV-VIS spectrophotometer (Shimadzu UV PC-1600) against blank. Here Standard Gallic acid was used and Total phenol contents of the fractions were expressed as Gallic acid equivalents (GAE) and calculated from

$\mathrm{C}=(\mathrm{c} \times \mathrm{V}) / \mathrm{m} \quad$ i.e., $(1)$

Where $\mathrm{C}$ is the total content of phenolic compounds, $\mathrm{mg} / \mathrm{g}$ plant extract in GAE, $\mathrm{c}$ is the concentration of Gallic acid obtained from calibration curve $(\mathrm{mg} / \mathrm{ml}, \mathrm{V}$ is the volume of the sample solution $(\mathrm{ml})$ and $\mathrm{m}$ is the weight of the sample $(\mathrm{g})$.

\subsubsection{Determination of Total Flavonoids Content}

Total flavonoid contents of the plant fractions were determined by Quercetin equivalents $(\mathrm{QE}){ }^{[17]} .1 .0 \mathrm{ml}$ plant extracts $(200 \mu \mathrm{g} / \mathrm{ml})$ and standard (quercetin) was added to $3 \mathrm{ml}$ of methanol $200 \mu \mathrm{l}$ of $10 \%$ aluminium chloride solution. $200 \mu \mathrm{l}$ of $1 \mathrm{M}$ potassium acetate solution and $5.6 \mathrm{ml}$ of distilled water were added. Absorbance of the solution was measured at $415 \mathrm{~nm}$ using a spectrophotometer (Shimadzu UV PC-1600) against blank. Total flavonoid contents of the fractions were expressed as quercetin equivalents (QE) and calculated from

$\mathrm{C}=(\mathrm{c} \times \mathrm{V}) / \mathrm{m} \quad$ i.e., $(2)$

Where $\mathrm{C}$ is the total flavonoid contents, $\mathrm{mg} / \mathrm{g}$ plant extract in $\mathrm{QE}, \mathrm{c}$ is the concentration of quercetin obtained from calibration curve $(\mathrm{mg} / \mathrm{ml}), \mathrm{V}$ is the volume of the sample solution $(\mathrm{ml})$ and $\mathrm{m}$ is the weight of the sample (g).

\subsubsection{Determination of Total Antioxidant Capacity}

Total antioxidant capacity of the plant extractives was determined by ascorbic acid equivalents (AAE) ${ }^{[18]} .300 \mu \mathrm{l}$ of each fraction $(200 \mu \mathrm{g} / \mathrm{ml})$ and standard (ascorbic acid) in different concentrations were taken in test tubes. $3 \mathrm{ml}$ of reagent solution $(0.6 \mathrm{M}$ sulfuric acid, $28 \mathrm{mM}$ sodium phosphate and $4 \mathrm{mM}$ ammonium molybdate) was added into the test tubes. Absorbance of the solution was measured at $695 \mathrm{~nm}$ using a spectrophotometer (Shimadzu UV PC-1600) against blank after cooling to room temperature. Total antioxidant capacity is expressed as the number of equivalents of ascorbic acid and calculated from

$\mathrm{A}=(\mathrm{c} \times \mathrm{V}) / \mathrm{m} \quad$ i.e., $(3)$ 
Where $\mathrm{A}$ is the total antioxidant capacity, mg/g plant extract, in ascorbic acid equivalents (AAE), c is the concentration of ascorbic acid obtained from calibration curve $(\mathrm{mg} / \mathrm{ml}), \mathrm{V}$ is the volume of the sample solution $(\mathrm{ml})$ and $\mathrm{m}$ is the weight of the sample $(\mathrm{g})$.

\subsubsection{DPPH Free Radical Scavenging Assay}

The free radical scavenging activity of the extract, based on the scavenging activity of the stable 1, 1diphenyl-2- picrylhydrazyl (DPPH) free radical was determined by the method described by Braca et al. (2001) [19]. Plant extract $(1.0 \mathrm{ml}$ ) and standard (ascorbic acid) was added to $2 \mathrm{ml}$ of a $0.004 \%$ methanol solution of DPPH. Absorbance at $517 \mathrm{~nm}$ was determined after $30 \mathrm{~min}$, and the percentage inhibition activity was calculated from

$\left[\left(\mathrm{A}_{0}-\mathrm{A}_{1}\right) / \mathrm{A}_{0}\right] \times 100$ i.e., (4)

Where $A_{0}$ is the absorbance of the control, and $A_{1}$ is the absorbance of the extract/ standard. The inhibition curves were prepared and $\mathrm{IC}_{50}$ values were calculated.

\subsubsection{Nitric Oxide Scavenging Capacity Assay}

Nitric oxide radical scavenging was estimated on the basis of Griess Illosvoy reaction ${ }^{[20]}$. In this investigation, Griess-Illosvoy reagent was modified by using naphthyl ethylene diamine dihydrochloride $(0.1 \%$ $\mathrm{w} / \mathrm{v}$ ) instead of 1-napthylamine (5\%). $4.0 \mathrm{ml}$ of each fraction and standard (ascorbic acid) was added into 1.0 $\mathrm{ml}$ of Sodium nitroprusside $(5 \mathrm{mM})$ solution and incubated for 2 hours at $300 \mathrm{C}$ to complete reaction. Then 2.0 $\mathrm{ml}$ solution was withdrawn from the mixture and mixed with $1.2 \mathrm{ml}$ of Griess reagent and absorbance of the solution was measured at $550 \mathrm{~nm}$ using a spectrophotometer (Shimadzu UV PC-1600) against blank. Percentage scavenging activity was calculated from

$\left[\left(\mathrm{A}_{0}-\mathrm{A}_{1}\right) / \mathrm{A}_{0}\right] \times 100$ i.e., (5)

Where $A_{0}$ is the absorbance of the control, and $A_{1}$ is the absorbance of the extract/ standard. The inhibition curves were prepared and $\mathrm{IC}_{50}$ values were calculated.

\subsubsection{Lipid Peroxidation (LPO) Assay}

Lipid peroxidation by Thiobarbituric Acid (TBA) Assay has been established as a major mechanism of cellular injury in many biological systems of plant and animal origin was determined following the method described by Placer ZA et al (1996) ${ }^{[21]}$. Normal albino rats were used for the preparation of liver homogenate. The perfused liver was isolated, and $10 \%(\mathrm{w} / \mathrm{v})$ homogenate was prepared using a homogenizer (Polytron PT1200C) at $0-4{ }^{\circ} \mathrm{C}$ with $0.15 \mathrm{M} \mathrm{KCl}$. The homogenate was centrifuged at $800 \mathrm{~g}$ for $15 \mathrm{~min}$ and clear cell-free supernatant was used for the study of in-vitro lipid peroxidation. $1.0 \mathrm{ml}$ plant extracts of different concentrations was added to $1 \mathrm{ml}$ of $0.15 \mathrm{M} \mathrm{KCl}$ and then $0.5 \mathrm{ml}$ of liver homogenate was added to it and mixed well. Then 100 $\mu \mathrm{l}$ of $0.2 \mathrm{mM} \mathrm{FeCl}_{3}$ solution was added to initiate peroxidation. The total mixture was incubated at $37{ }^{\circ} \mathrm{C}$ for $30 \mathrm{~min}$. After the incubation the reaction was terminated by the addition of $2 \mathrm{ml}$ of ice-cold $0.25 \mathrm{~N} \mathrm{HCl}$ containing $15 \%$ TCA, $0.38 \%$ TBA and $0.5 \%$ BHT. The reaction mixture was heated at $80{ }^{\circ} \mathrm{C}$ for 60 min. The sample was cooled and centrifuged, and the absorbance of the supernatant was measured at $532 \mathrm{~nm}$ and Inhibition of Lipid Peroxidation was calculated from

$\left[\left(\mathrm{A}_{0}-\mathrm{A}_{1}\right) / \mathrm{A}_{0}\right] \mathrm{x} 100$ i.e., (5)

Where $A_{0}$ is the absorbance of the control, and $A_{1}$ is the absorbance of the extract/ standard. The inhibition curves were prepared and $\mathrm{IC}_{50}$ values were calculated.

\subsubsection{Cupric Reducing Antioxidant Capacity}

Cupric reducing antioxidant capacity of the plant extracts was determined following the method described by Resat et al. (2004) ${ }^{[22]}$. $500 \mu \mathrm{l}$ of each fraction and standard (ascorbic acid) in different concentrations were taken in test tubes. $1.0 \mathrm{ml}$ of $0.01 \mathrm{M} \mathrm{CuCl}_{2} .2 \mathrm{H} 2 \mathrm{O}$ solution and $1.0 \mathrm{ml}$ of ammonium acetate buffer (pH 7.0) was added into the test tubes. Then $1.0 \mathrm{ml}$ of $0.0075 \mathrm{ml}$ of Neocaproin solution and $600 \mu \mathrm{l}$ of distilled water was added into the test tubes. The total mixture was incubated for 1 hour at room temperature then the absorbance of the solution was measured at $450 \mathrm{~nm}$ using a spectrophotometer (Shimadzu UV PC1600) against blank.

\subsubsection{Total alkaloid Content Determination}

Total alkaloid content was determined by slightly modified Fazel et al., 2008 method ${ }^{[26]}$. The plant extract $(1 \mathrm{mg} / \mathrm{ml})$ was dissolved in $2 \mathrm{~N} \mathrm{HCl}$ and then filtered. The $\mathrm{pH}$ of phosphate buffer solution was adjusted to neutral with $0.1 \mathrm{~N} \mathrm{NaOH}$ and then $5 \mathrm{ml}$ of BCG solution along with $5 \mathrm{ml}$ of phosphate buffer were added. The extracts were collected in a $10 \mathrm{ml}$ volumetric flask and diluted to volume with chloroform. The absorbance 
of the complex in chloroform was measured at $470 \mathrm{~nm}$. All experiments were performed thrice; the results were averaged and reported in the form of Mean \pm S.D.

\subsubsection{Total Tannin Content Determination}

The tannins were determined by slightly modified Folin and Ciocalteu method ${ }^{[15]}{ }^{[16]}$. Briefly, $1 \mathrm{ml}$ of the sample extract is added with $7.5 \mathrm{ml}$ of distilled water and adds $0.5 \mathrm{ml}$ of Folin Phenol reagent, $1 \mathrm{ml}$ of $35 \%$ sodium carbonate solution. The absorbance was measured at $725 \mathrm{~nm}$. Tannic acid was used as standard solutions. The results of tannins are expressed in terms of tannic acid in $\mathrm{mg} / \mathrm{g}$ of extract.

2.5. Brine Shrimp lethality bioassay for cytotoxic activity (BSLA)

Cytotoxicity of the plant extractives was determined by Brine Shrimp lethality bioassay described by Meyer et al. (1982) ${ }^{[23]}$. Brine Shrimp eggs are hatched in simulated seawater to get nauplii. Sample solutions are prepared by dissolving the test materials in pre-calculated amount of DMSO (Di-methyl sulphoxide). Ten nauplii are taken in vials containing $5 \mathrm{ml}$ of simulated seawater. The samples of different concentrations are added. Survivors are counted after 24 hours. The median lethal concentration, LC $_{50}$ values of the test samples after 24 hours are obtained by a plot of percentage of dead Shrimps against the logarithm of the sample concentration using Microsoft Excel. Vincristine sulphate is usually used as the reference cytotoxic drug ${ }^{[24]}$.

\subsection{Antimicrobial Screening}

Among the available techniques for antimicrobial screening the disc diffusion is a widely accepted in vitro investigation for preliminary screening of test agents which may possess antimicrobial activity. Sterile nutrient agar plates (Muller-Hinton agar medium) were prepared and incubated at $37^{\circ} \mathrm{C}$ for $24 \mathrm{~h}$ to check for any contamination. Sterile filter paper discs of $5 \mathrm{~mm}$ diameter were soaked in three different dilutions of the ethanolic extract and placed in appropriate position on the surface of the plate with quadrants marked at the back of the petri dishes. The in vitro antibacterial activity of different extracts of Zizyphus rugosa Lam. at 30, 60 and $90 \mu \mathrm{g} / \mu \mathrm{l}$ was studied by disc diffusion method ${ }^{[25]}$ against Escherichia coli, Bacillus subtilis, Staphylococcus aureus, S. epidermidis, Pseudomonos aeruginosa and Proteus vulgaris. The Petri dishes were incubated at $37^{\circ} \mathrm{C}$ for $24 \mathrm{~h}$ and the diameter of the zone of inhibition measured in $\mathrm{mm}$. The activity of the ethanolic extract was compared with Chloramphenicol $(50 \mu \mathrm{g} / \mathrm{disc})$. The zone of inhibition was calculated by measuring the minimum dimensions of the zone of no microbial growth around the disc and minimum inhibitory concentrations were determined.

\subsection{Statistical analysis}

The inhibition curves were prepared and $\mathrm{IC}_{50}$ values were obtained with the help of Microsoft excel 2007.

\subsection{Phytochemical screening}

\section{RESULTS}

Preliminary phytochemical screening of the crude extracts of different parts of Zizyphus rugosa (Lam.) revealed the presence of different kind of chemical groups that are summarized in Table: 1.

Table-1: Result of chemical group test of Ethanolic leaf extract (ZLE) of Zizyphus rugosa Lam

\begin{tabular}{|c|c|c|c|c|c|c|c|c|c|c|c|c|}
\hline \multirow{2}{*}{$\begin{array}{l}\text { Extr } \\
\text { act }\end{array}$} & \multicolumn{2}{|c|}{ Carbohydrate } & \multicolumn{2}{|c|}{ Glycoside } & \multicolumn{4}{|c|}{ Alkaloid } & \multirow[b]{2}{*}{$\begin{array}{l}\text { Ster } \\
\text { oids }\end{array}$} & \multirow[b]{2}{*}{$\begin{array}{l}\text { Tan } \\
\text { nin }\end{array}$} & \multirow[b]{2}{*}{$\begin{array}{l}\text { Flav } \\
\text { onoi } \\
\text { ds }\end{array}$} & \multirow[b]{2}{*}{$\begin{array}{l}\text { Sa } \\
\text { po } \\
\text { nin }\end{array}$} \\
\hline & $\begin{array}{l}\text { Molisch' } \\
\text { s test } \\
\text { (General } \\
\text { test for } \\
\text { Carbohy } \\
\text { drates) }\end{array}$ & $\begin{array}{l}\text { Fehlin } \\
\text { g's } \\
\text { test(for } \\
\text { reduci } \\
\text { ng } \\
\text { sugar) }\end{array}$ & $\begin{array}{l}\text { Gener } \\
\text { al test } \\
\text { for } \\
\text { glycos } \\
\text { ide }\end{array}$ & $\begin{array}{l}\text { Glu } \\
\text { cosi } \\
\text { de }\end{array}$ & $\begin{array}{l}\text { Maye } \\
\text { r's } \\
\text { Test }\end{array}$ & $\begin{array}{l}\text { Hag } \\
\text { er's } \\
\text { Test }\end{array}$ & $\begin{array}{l}\text { Wa } \\
\text { gner } \\
\text { Test }\end{array}$ & $\begin{array}{l}\text { Drag } \\
\text { endor } \\
\text { ff's } \\
\text { Test }\end{array}$ & & & & \\
\hline ZLE & ++ & - & - & - & + & + & + & + & + & + & - & ++ \\
\hline
\end{tabular}

$[+=$ Presence,$++=$ Strong presence, $-=$ Absence $]$

3.2. Antioxidant activity evaluation

\subsubsection{Total phenol content determination}

Total phenolic content of Zizyphus rugosa (Lam.) was determined by using the Folin-Ciocalteu reagent and were expressed as gallic acid equivalents (GAE) per gram of plant extract. The total phenolic contents of the test fractions were calculated using the standard curve of gallic acid $\left(y=0.008 x+0.101 ; R^{2}=0.967\right)$. Test fraction was found to contain $56.51 \pm 3.097 \mathrm{mg} / \mathrm{gm}$ Gallic acid equivalent (GAE). Result is shown in mean \pm SD. 


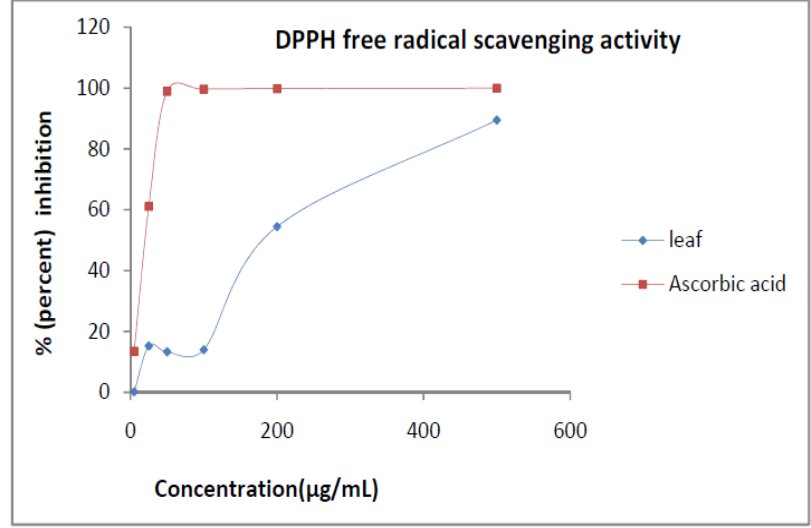

Fig 1: DPPH radical scavenging activity of ascorbic acid and Zizyphus rugosa (Lam.) leaf extract.

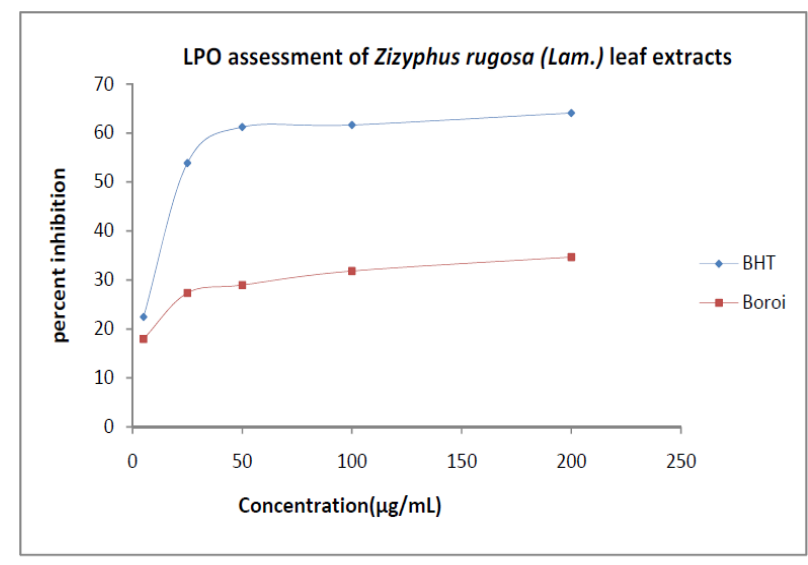

Fig 3: LPO assessment of BHT and Zizyphus rugosa (Lam.) leaf extracts.

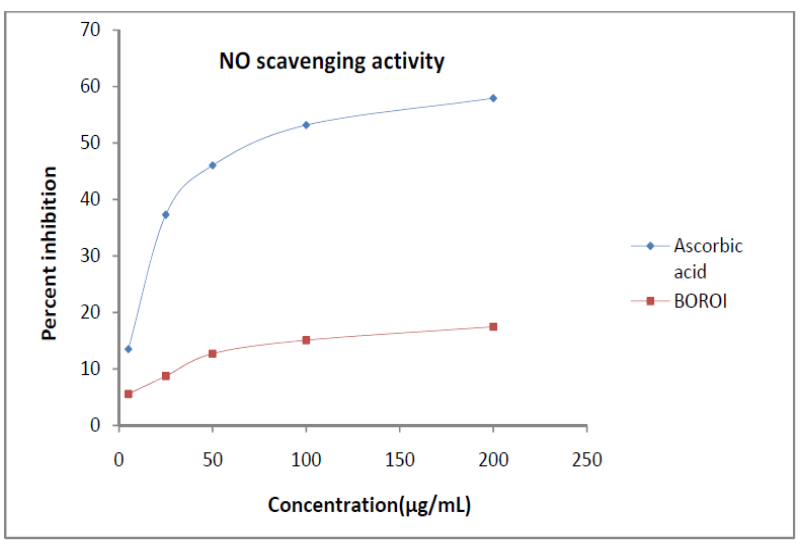

Fig 2: NO scavenging activity of ascorbic acid and Zizyphus rugosa (Lam.) leaf extracts.

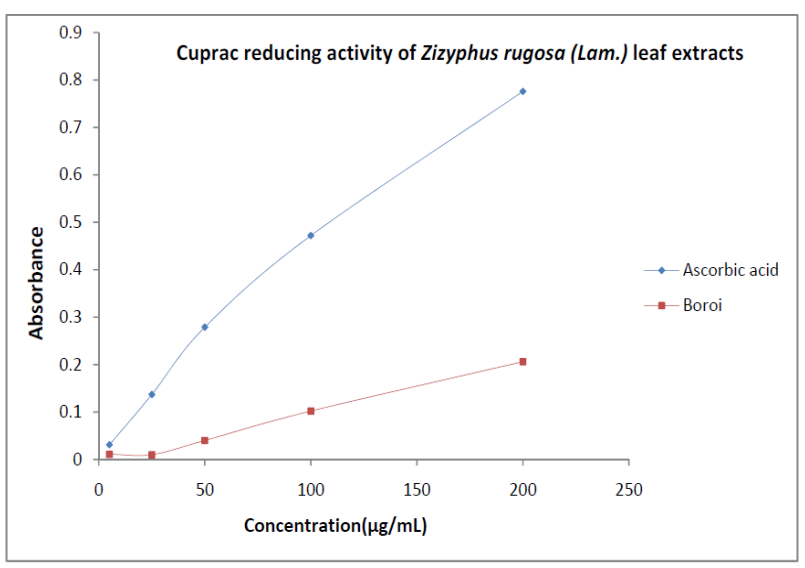

Fig 4: Cuprac reducing activity of ascorbic acid and Zizyphus rugosa (Lam.) leaf extracts.

\subsubsection{Determination of Total Flavonoids Content}

The total flavonoid content was calculated using the standard curve of quercetin $\left(y=0.005 x-0.005 ; R^{2}\right.$ $=0.996)$ and was expressed as quercetin equivalents $(\mathrm{QE})$ per gram of the plant extract determined by Aluminium chloride colorimetric method. Flavonoid contents of the fraction were found as $144.50 \pm 0.71 \mathrm{mg} / \mathrm{g}$ Quercetin equivalent (QAE). Result is shown in mean \pm SD.

\subsubsection{Determination of Total Antioxidant Capacity}

Total antioxidant capacity of the test samples was calculated using the standard curve of ascorbic acid $\left(\mathrm{y}=2.171 \mathrm{x}-1.639 ; \mathrm{R}^{2}=0.534\right)$. Leaf extract was found to show $9.32 \pm 0.074 \mathrm{mg} / \mathrm{g}$ AAE (Ascorbic acid equivalent) was evaluated by the phosphomolybdenum method. Result is shown in mean \pm SD.

\subsubsection{DPPH Free Radical Scavenging Assay}

The $\mathrm{IC}_{50}$ values of leaf extracts of Zizyphus rugosa (Lam.) is $179.713 \mu \mathrm{g} / \mathrm{mL}$ whereas standard drug ascorbic acid is found to show $\mathrm{IC}_{50}$ value of $15.707 \mu \mathrm{g} / \mathrm{mL}$. Comparison graph of ascorbic acid and Zizyphus rugosa (Lam.) leaf extract is given in Fig 1.

\subsubsection{Nitric Oxide Scavenging Capacity Assay}

Scavenging of NO was determined by the decrease in its absorbance at $550 \mathrm{~nm}$, induced by antioxidants. The extract showed $\mathrm{IC}_{50}$ value $769.909 \mu \mathrm{g} / \mathrm{mL}$ in comparison to ascorbic acid $82.642 \mu \mathrm{g} / \mathrm{mL}$. Comparison graph of ascorbic acid and Zizyphus rugosa (Lam.) leaf extracts is given in Fig 2.

\subsubsection{Lipid Peroxidation (LPO) Assay}

The decreased absorbance of pink chromogen produced from the reaction of TBA and malondialdehyde is a indication of inhibition of lipid peroxidation. The $\mathrm{IC}_{50}$ value of leaf extracts of Zizyphus 
rugosa (Lam.) is $402.835 \mu \mathrm{g} / \mathrm{mL}$ in comparison to standard drug BHT ( $\mathrm{IC}_{50}$ value $32.94 \mu \mathrm{g} / \mathrm{mL}$ ) which represents poor inhibition activity. The comparison graph is presented in Fig 3.

\subsubsection{Cupric Reducing Antioxidant Capacity}

Reduction of $\mathrm{Cu}^{2+}$ ion to $\mathrm{Cu}^{+}$was found to rise with increasing concentrations of the different extracts. The standard ascorbic acid showed highest reducing capacity. The leaf extracts of Zizyphus rugosa (Lam.) showed dose depended reducing capacity that is comparable to ascorbic acid presented in Fig 4 .

\subsubsection{Total alkaloid Content Determination}

Total Alkaloid content was calculated using the equation ( $\mathrm{y}=0.085 \mathrm{x}-0.048, \mathrm{R}^{2}=0.812$ ). The amount of total alkaloid of Zizyphus rugosa (Lam.) leaf extracts calculated is $26.128 \pm 1.998 \mathrm{mg} / \mathrm{gm}$, Atropine equivalent (AE).

\subsubsection{Total Tannin Content Determination}

Tanin content was calculated using the equation $\left(\mathrm{y}=0.464 \mathrm{x}-0.305, \mathrm{R}^{2}=0.66\right)$ from the calibration curve given below. The amount of tannin of leaf extracts of Zizyphus rugosa (Lam.) calculated is $47.585 \pm 1.336$ $\mathrm{mg} / \mathrm{gm}$, Tannic acid equivalent (TAE).

\subsection{Brine Shrimp lethality bioassay for cytotoxic activity (BSLA)}

In this study, leaf extracts of Zizyphus rugosa (Lam.) found to be the Good toxic to Brine Shrimp nauplii, with $\mathrm{LC}_{50}$ of $212.402 \mu \mathrm{g} / \mathrm{ml}$ whereas anticancer drug vincristine sulphate showed $\mathrm{LC}_{50}$ value $2.47 \mu \mathrm{g} / \mathrm{ml}$.

\subsection{Antimicrobial Screening}

The result of antimicrobial screening of leaf extracts of Zizyphus rugosa (Lam.) is given below in a table. Chloramphenicol is used as standard that are summarized in Table: 2

Table-2: Result of Antimicrobial Screening

\begin{tabular}{|l|l|l|}
\hline \multirow{2}{*}{ Test Organisms } & \multicolumn{2}{|l|}{$\begin{array}{l}\text { Inhibition Zone Diameter }(\mathrm{mm}) \text { in } \\
\text { mean } \pm \text { SD }\end{array}$} \\
\cline { 2 - 3 } & Chloramphenicol & leaf extracts \\
\hline Salmonella typhi & 1 & No \\
\hline Staphylococcus aureus & 25.5 & No \\
\hline Shiggla sonni & 28.5 & 8 \\
\hline Salmonella paratyphi & 13 & No \\
\hline Salmonella grb & 7 & No \\
\hline
\end{tabular}

\section{Discussions}

Leaf extracts of Zizyphus rugosa (Lam.) have been shown to possess phytoconstituents including carbohydrates (monosaccharides, reducing and mixed-reducing sugars), alkaloid, glycosides, steroids, tannins and saponin. The results of Total phenolic content strongly suggest that phenolics are important components of the tested plant extracts Zizyphus rugosa (Lam.) leaf extract showed moderate phenolic content which is showed in gallic acid equivalent.

The antioxidative properties of flavonoids are due to several different mechanisms, such as scavenging of free radicals, chelation of metal ions, such as iron and copper, and inhibition of enzymes responsible for free radical generation. There are also reports on the role of flavonoid, a powerful antioxidant ${ }^{[27,28]}$ Depending on their structure; flavonoids are able to scavenge practically all known ROS. The leaf extract of Zizyphus rugosa (Lam.) has been shown to possess good amount of flavonoids. According to recent reports, a highly positive relationship between total phenols and antioxidant activity appears to be the trend in many plant species. Zizyphus rugosa (Lam.) leaf extracts showed moderate content of total phenol which is showed in gallic acid equivalent.

In DPPH radical scavenging assays, the leaf extracts of Zizyphus rugosa (Lam.) showed dose dependent scavenging of DPPH radicals in a way similar to that of the reference antioxidant ascorbic acid (Fig 1). DPPH radical scavenging is a popular and reliable method for screening the free radical scavenging activity of compounds or antioxidant capacity of plant extracts ${ }^{[24]}$.This extract has electron donating ability to DPPH radical.

In Nitric Oxide Scavenging Capacity Assay, based on $\mathrm{IC}_{50}$ value of standard drug ascorbic acid, we speculate that nitric oxide scavenging activity of Zizyphus rugosa (Lam.) leaf extracts may have moderate relevance in the prevention and control of disorders where NO is thought to play a key role (Fig 2). NO 
scavenging capacity of the extract may help to arrest the chain of reactions initiated by excess generation of NO that are detrimental to the human health. Nitric oxide is also implicated for inflammation, cancer and other pathological conditions ${ }^{[29]}$. The leaf extracts of Zizyphus rugosa (Lam.) has been shown to possess moderate amount of Alkaloids through total alkaloid content determination.

Tannin like polyphenolic compound is used as a sword to destroy the free radicals and saves cellular macromolecules. By doing this method leaf extracts of Zizyphus rugosa (Lam.) has been shown to possess moderate amount tannin content which should be further investigated to identify the potential chemical compounds. Tannins present in the plant extract, as evident from phytochemical screening, may be responsible for the antioxidant action.

Polyphenolic compounds, like flavonoids, tannins and phenolic acids, commonly found in plants have been reported to have multiple biological effects, including antioxidant activity ${ }^{[27,28,30,31]}$. A direct correlation between antioxidant capacity and reducing power of certain plant extracts has been reported ${ }^{[32]}$. Reducing power is associated with antioxidant activity and may serve as a significant reflection of the antioxidant activity [33]. Compounds with reducing power indicate that they are electron donors and can reduce the oxidized intermediates of lipid peroxidation processes, so that they can act as primary and secondary antioxidants ${ }^{[34]}$. Therefore, antioxidants with free radical scavenging activities may have great relevance in the prevention and treatment of diseases associated with oxidants or free radicals ${ }^{[35]}$.

Most of the hepatotoxic chemicals damage liver mainly by inducing lipid peroxidation directly or indirectly. In higher animals, lipid peroxidation was known to cause destabilization and disintegration of the cell membrane, leading to liver injury, arteriosclerosis and kidney damage ${ }^{[36]}$. Peroxy radicals are important agents that mediate lipid peroxidation thereby damaging cell membrane.

In Brine Shrimp Lethality Bioassay the leaf extracts of Zizyphus rugosa (Lam.) has showed Good potentiality. This concentration dependent increment in percent mortality of Brine Shrimp nauplii produced by Zizyphus rugosa (Lam.) indicates the presence of cytotoxic principles in this extract ${ }^{[23]}$. In antimicrobial screening leaf extracts of Zizyphus rugosa (Lam.) exhibited antimicrobial activity only against one bacteria and it's probably attributed to the presence of alkaloids.

\section{Conclusion}

The results from the experiments confirmed that the Ethanolic leaf extract of Zizyphus rugosa Lam. in general, possesses moderate antioxidant and good cytotoxic properties. Different crude extracts of Zizyphus rugosa Lam. (Fam. Rhamnaceae) were subjected to vigorous phytochemical and pharmacological investigations to validate the traditional use and to find out any other therapeutic activities. On the basis of the result obtained from this present investigation, we can also conclude that the leaf ethanol extract of Zizyphus rugosa Lam. have moderate anti-microbial activity. Various phytochemical constituents like terpenoid, glycoside and steroid present in the plant, which may be responsible for the observed activities. The good toxicity exerted by the extracts of Zizyphus rugosa Lam. in brine shrimp lethality bioassay suggests bioactive principles in the plant. The aerial part of the plant exhibited potential antioxidant activity. However, further studies are suggested to be undertaken to understand the underlying mechanism of the observed activities and to isolate, purify and characterise active phytochemical ingredient(s) responsible for these bioactivities in animal models and to carry out advance research on cancer because the other plants of Rhamnaceae family have significant cytotoxic and inhibitory activity on tumors of various types of cancers.

\section{Acknowledgement}

I am greatly thankful to Dr. Md. Sohel Rana, Professor, Department of Pharmacy, Jahangirnagar University, for providing necessary facilities, logistic support, and continuous encouragement to carry out this research.

\section{References}

[1] Clardy J., Walsh C., 2004. Lessons from natural molecules, Nature. 432 (7019): 829-837.

[2] Koehn F.E., Carter G.T., 2005. The evolving role of natural products in drug discovery. Nat. Rev. Drug Discovery, 4 (3): 206-220.

[3] Muhammad Ashikur Rahman et al, (February 2009). Phytochemical \& Pharmacological Screening on the Fruits of Terminalia belerica. Thesis submitted to JU pharmacy department. pp2-4

[4] Ncube, NS; Afolayan, AJ; Okoh, AI. 2008. Assessment techniques of antimicrobial properties of natural compounds of plant origin: current methods and future trends. African journal of Biotechnology; 7(12); 1797-1806.

[5] Ghani A., 2003. Medicinal Plants of Bangladesh. $2^{\text {nd }}$ Ed. The Asiatic Society of Bangladesh. Dhaka, Bangladesh, PP 31, 39-40, 418, 500-504, 589-580.

[6] Musselman, L.J, 1999. Holy Pharmacy. Modern medical uses of some plants of the Quran and the Bible: Its relation to biodiversity.

[7] Sofowora A., 1981. Inaugural Lecture, Series No. 48, University of Ife press, Ile-Ife, Nigeria.

[8] Edgar J., Da Silva., Baydoun E., Badran A., 2002. Biotechnology and the developing world. Electronic Journal of Biotechnology $5(1)$. 


\section{Phytochemical, cytotoxic, in-vitro antioxidant and anti-microbial investigation of ethanolic leaf}

extract of Zizyphus rugosa lam.

[9] Mia A.W., Ghani A., 1990. In: Ghani A (ed), Traditional medicine, Pharmacy Department, Jahangirnagar University, Savar, Dhaka, Bangladesh. Pp: 10-12.

[10] Kirtikar K.R, Basu B.D, Blatter E, Cains J.F., Mhaskar K.S.; Indian Medicinal Plants, Vol. 1, Lalit Mohan Basu, Allahabad, India 1975 , p. 594

[11] Erenmemisoglu, A., Kelestimur, F., Koker, A. H., Ustan, H., Tekol, Y. and Ustdal, M. 1995. J. Pharmacy \& Pharmacology 41, 72.

[12] Anand, K. K., Singh, B., Chand, D., Chandan, B. K. and Gupta, V.N. 1989. J. Ethnopharmacology $27,121$.

[13] M. Shoeb, M. I. R. Mamun, N. Nahar and M. Mosihuzzaman., 2005, Biological Screening of Zizyphus rugosa and Zizyphus oenoplia extractives, Dhaka Univ. J. Pharm. Sci. 4(2): 131-134

[14] Vinayaka KS, Ravindra P, Kumaraswamy HG, 2011, Nutritive composition of fruit of Zizyphus rugosa Lam, Research and Reviews in Biomedicine and Biotechnology [RRBB], 2(1\&2), 20-24

[15] Velioglu Y. S., Mazza G., Gao L., Oomah B. D., 1998. Antioxidant activity and total phenolics in selected fruits, vegetables and grain products. J Agric Food Chem., 46: 4113-17.

[16] Yu L., 2001. Free radical scavenging properties of conjugated linoleic acids. J Agric Food Chem. 49: 3452-3456

[17] Kumaran A., Karunakaran R. J., 2006. Antioxidant and free-redical scavenging activity of an aqueous extract of Coleus aromaticus. Food Chem., 97: 109-114.

[18] Prieto P., Pineda M., Aguilar M., 1999. Spectrophotometric quantitation of antioxidant capacity through the formation of a phosphomolybdenum complex: Specific application to the determination of vitamin E. Anal Biochem., 269: 337- 341.

[19] Braca A., Tommasi N. D., Bari L. D., Pizza C., Politi M., Morelli I., 2001. Antioxidant principles from Bauhinia terapotensis. J Nat Prod., 64: 892-895.

[20] Govindarajan R, Rastogi S, Vijayakumar M, ShirwaikarA, Rawat AKS, Mehrotra S and Palpu P. 2003. Studies on the Antioxidant Activities of Desmodium gangeticum. Biol Pharm Bull. 26 : 1424-1427.

[21] Placer Z.A., Cushman L.L. and Johnson B.C. (1966). Estimation of product of lipid peroxidation (malonyldialdehyde) in biochemical systems. Anal. Biochem. 16, 359-364.

[22] Resat A., Kubilay G., Mustafa O., Saliha E. K., 2004. Novel total antioxidant capacity index of dietary polyphenols and vitamin C and E, using their cupric ion reducing capability in the presence of neocuproine: CUPRAC Method. J. Agric. Food Chem., 52: 7970-7981.

[23] Meyer B. N., Ferrigni N. R., Putnam J. E., Jacobsen L. B., 1982. Brine shrimp: A convenient general bioassay for active plant constituents. Planta Med., 45: 31-34.

[24] Brand-Willams W., Cuvelier M. E., Berset C., 1995. Use of a free radical method to evaluate antioxidant activity. LebensmittelWissenschaft Technologie. 28: 25-30.

[25] Pelczar MJ, Chan ECS, krieg NR (1993). Microbiology: Concept and Application International edition McGraw-Hill, USA. Pp 281-324.

[26] Fazel Shamsa, Hamidreza Monsef, Rouhollah Ghamooshi ,Mohammadreza Verdian-rizi. Spectrophotometric determination of total alkaloids in some Iranian medicinal plants. Thai J. Pharm. Sci 2008; 32: 17-20.

[27] Brown, J.E. and C.A. Rice-Evans, 1998. Luteolinrich artichoke extract protects low density lipoprotein from oxidation in vitro. Free Rad. Res., 29: 247-255.

[28] Vinson, J.A., Y.A. Dabbagh, M.M. Serry and J. Jang, 1995. Plant flavonoids, especially tea flavonols are powerful antioxidant s using an in vitro oxidation model for heart disease. J. Agric. Food Chem., 43: 2800-2802

[29] Moncada, A., R.M.J. Palmer and E.A. Higgs, 1991. Nitric oxide: Physiology, pathophysiology and pharmacology. Pharmacol. Rev., 43: 109-142.

[30] Gil, M.I., F. Ferreres and F.A. Tomás-Barberán, 1999. Effect of postharvest storage and processing on the antioxidant constituents (flavonoids and vitamin C) of fresh-cut spinach. J. Agric. Food Chem., 47: 2213-2217.

[31] Kähkönen, M.P., A.I. Hopia, H.J. Vuorela, J.P. Rauha, K. Pihlaja, T.S. Kujala and M. Heinonen, 1999. Antioxidant activity of plant extracts containing phenolic compounds. J. Agric. Food Chem., 47: 3954-3962.

[32] Tanaka, M., C.W. Kuie, Y. Nagashima and T. Taguchi, 1988. Applications of antioxidative Maillard reaction products from histidine and glucose to sardine products. Nippon Suisan Gakkaishi, 54: 1409-1414.

[33] Oktay M., Gulcin I., and Kufrevioglu O. I., 2003. Deter mination of in vitro antioxidant activity of fennel (Foeniculum vulgare) seed extracts. Lebensm. Wiss. Technol. - Food Sci. Technol. 36, 263-271.

[34] Yen G.-C., Chen H.-Y. (1995): Antioxidant activity of various tea extracts in relation to their antimutagenicity. J. Agr. Food Chem., 43: 27-32.

[35] Soares, J.R., T.C.P. Dinis, A.P. Cunha and L.M. Almeida, 1997. Antioxidant activities of some extracts of thymus zygis. Free Rad. Res., 26: 469-478.

[36] Leonard T. Rael, Gregory W. Thomas, 2004 Lipid Peroxidation and the Thiobarbituric Acid Assay: Standardization of the Assay When Using Saturated and Unsaturated Fatty Acids. Journal of Biochemistry and Molecular Biology, 37: 749-752. 